\title{
PENGARUH PEMBERIAN KAPSUL KELOR TERHADAP PRODUKSI ASI
}

\author{
Yuliati Shoffiyah ${ }^{1}$, Achmad Farich $^{2}$, Dainty Maternity ${ }^{3}$, Ike Ate Yuviska ${ }^{4}$ \\ 1,2,3Program Studi DIV Kebidanan Universitas Malahayati \\ 4Program Studi DIII Kebidanan Universitas Malahayati \\ ${ }^{1}$ email yuliatishoffiyah@gmail.com \\ 2email Farichrich@malahayati.ac.id \\ 3email denty.mf@gmail.com \\ 4email ike yuviska12345@gmail.com
}

\section{ABSTRACT : THE EFFECT OF GIVING MORINGA CAPSULES ON BREAST MILK PRODUCTION}

Background In Indonesia, the proision of breastfeeding eclusiely for si months just reached $30.2 \%$ case is still far from the target that $80 \%$ regard it in because of lack of awareness of society in encouraging an increase in the proision of breastfeeding eclusiely, lack of knowledge of mothers, families and communities about the importance of breastfeeding eclusiely.

The purpose of this study was to determine the effect of morngaoliefera leaf capsules on breast milk production in the working area puskesmas of Gedung Sari Lampung entral Health enter in 2019.

MethodsThis type of uantitatie research with a research design using a pre experimental approach with a pretest and post test with control group design. Samples of all nursing mothers were 40 people. The population of breastfeeding mothers is 79 people. 20 people as a group eperiment and 20 people as a group control with the techniue of sampling purposive sampling .Anilsa the data to test T-test independent.Results of the study is to show the aeragefreuency before administration of the capsule leaes of oringa to the production of breast milk in the region work PuskesmasGedung Sari entral Lampung in 2019 ie 26.50 , the aeragefreuency after administration of the capsule leaes of oringa to the production of breast milk in the region work Puskesmasuilding Sari Lampung The middle of 2019 is 80.50 , and there is an influence of giingoringa leaf capsules to the production of breast milk in the working area of the Sari Lampung entral Health enter in 2019.

ConclusionT test results obtained $p$ value $0,000<\alpha(0,05$ there is an effect of consumption of Moringa leaf capsules on milk production).

Suggestions for the public are expected that mothers want to consume Moringa leaf capsules in accordance with the recommendations because Moringa capsules can increase milk production.e

Keywords : Moringa leaf capsules giving, Production ASI

\section{ABSTRAK}

Latar Belakang Di Indonesia pemberian ASI eksklusif selama enam bulan baru mencapai 30,2\% hal ini masih jauh dari target yaitu $80 \%$ halini di karenakan rendahnya kesadaran masyarakat dalam mendorong peningkatan pemberian ASI eksklusif, kurangnya pengetahuan ibu, keluarga serta masyarakat tentang pentingnya ASI eksklusif.

Tujuan dari penelitian ini adalah mengetahui pengaruh pemberian kapsul daun kelor terhadap produksi ASI di wilayah kerja Puskesmas Gedung Sari Lampung Tengah Tahun 2019.

Metode Jenis penelitian kuantitatif dengan rancangan penelitian menggunakan pendekatan pre experimental dengan rancangan pretest dan post test with control group. Populasi ibu menyusui sebanyak 79 orang. Sampel seluruh ibu menyusui sebanyak 40 orang. 20 orang sebagai kelompok eksperimen dan 20 orang sebagai kelompok kontrol dengan teknik sampling purposive sampling. Analisa data dengan uji T-test independent.

Hasil penelitian ini menunjukan rata-rata frekuensi sebelum pemberian kapsul daun kelor terhadap produksi ASI di wilayah kerja Puskesmas Gedung Sari Lampung Tengah Tahun 2019 Tahun 2019 Yaitu 26.50, rata-rata frekuensi sesudah pemberian kapsul daun kelor terhadap produksi ASI di wilayah kerja Puskesmas Gedung Sari Lampung Tengah Tahun 2019 Yaitu 80.50, serta ada pengaruh pemberian pemberian kapsul daun kelor terhadap produksi ASI di wilayah kerja Puskesmas Gedung Sari Lampung Tengah Tahun 2019.

Kesimpulan ada pengaruh konsumsi kapsul daun kelor terhadap produksi ASI. 
Saran untuk masyarakat diharapkan para ibu mau mengkonsumsi kapsul daun kelor sesuai dengan anjuran karena kapsul kelor dapat meningkatkan produksi ASI.

Kata kunci: Pemberian Kapsul Daun Kelor, Produksi ASI

\section{PENDAHULUAN}

Menyusui sejak dini mempunyai dampak yang positif baik bagi ibu maupun bayinya. Bagi bayi, menyusui mempunyai peran penting untuk menunjang pertumbuhan, kesehatan, dan kelangsungan hidup bayi karena Air Susu Ibu (ASI) kaya dengan zat gizi dan antibody. Sedangkan bagi ibu, menyusui dapat mengurangi morbiditas dan mortalitas karena proses menyusui akan merangsang kontraksi uterus sehingga mengurangi pendarahan pasca melahirkan (postpartum). (Badan Penelitian dan Pengembangan Kesehatan, 2013)

Menyusui dalam jangka panjang dapat memperpanjang jarak kelahiran karena masa amenorhe lebih panjang. UNICEF dan WHO membuat rekomendasi pada ibu untuk menyusui eksklusif selama 6 bulan kepada bayinya. Sesudah umur 6 bulan, bayi baru dapat diberikan makanan pendamping ASI (MP-ASI) dan ibu tetap memberikan ASI sampai anak berumur minimal 2 tahun. Pemerintah Indonesia melalui kementrian kesehatan juga merekomendasikan para ibu untuk menyusui eksklusif pada bayinya selama 6 bulan. (Badan Penelitian dan Pengembangan Kesehatan, 2013)

Di Indonesia pemberian ASI eksklusif selama enam bulan baru mencapai $30,2 \%$ hal ini masih jauh dari target yaitu $80 \%$ hal ini di karenakan rendahnya kesadaran masyarakat dalam mendorong peningkatan pemberian ASI eksklusif, kurangnya pengetahuan ibu, keluarga serta masyarakat tentang pentingnya ASI eksklusif. (Badan Penelitian dan Pengembangan Kesehatan, 2013)

Sedangkan di Provinsi Lampung, pemberian ASI lebih dari 48 jam hanya $12,0 \%$ hal ini masih sangat jauh dari target. (Badan Penelitian dan Pengembangan Kesehatan, 2013)

Menurut data dari profile kesehatan, di Lampung Tengah pencapaian bayi yang di berikan ASI esklusif $62,66 \%$. Hal ini belum mencapai target yang di harapkan yaitu $80 \%$. (Dinas Kesehatan, 2016).

Kenyataan di lapangan menunjukan bahwa produksi ASI yang sedikit pada hari pertama setelah melahirkan menjadi kendala dalam pemberian ASI secara dini. Namun, menurut Roesli (2013) telah membuktikan bahwa tidak ada ibu yang kekurangan produksi ASI. Pada 100 ibu yang menyusui ternyata hanya ada dua ibu yang benar-benar produksi ASInya sedikit.

Keberhasilan menyusui bukan suatu yang datang dengan sendirinya, tetapi merupakan keterampilan yang perlu di ajarkan. Selain itu persiapan fisik, psikologis serta gizi ibu saat menyusui juga sangat dibutuhkan untuk keberhasilan menyusui. (Prawirohardjo, 2014)

Daun kelor atau Moringa oleifera milik keluarga Moringaceae adalah efektif obat untuk malnutrisi. Moringa kaya akan nutrisi karena untuk Kehadiran berbagai phytochemical penting hadir dalam nya daun, polong dan biji.

Daun kelor adalah bagian yang banyak mengandung manfaat secara umum dapat dikonsumsi karena mengandung gizi dan protein yang tinggi. (Yusni, 2009)

\section{METODE PENELITIAN}

Dalam penelitian ini menggunakan jenis penelitian kuantitatif, jenis penelitian ini merupakan jenis penelitian untuk mendapatkan gambaran yang akurat dari sebuah karakteristik masalah yang mengklarifikasikan suatu data dan pengambilan data yang berhubungan dengan angk-angka baik yang diperoleh dari hasil pengukuran maupun dari nilai suatu data yang diperoleh. (Notoatmodjo, 2018)

Dalam penelitian ini, peneliti menggunakan rancangan analisis dengan menggunakan pendekatan pre experimental desain yaitu eksperimen yang sering kali dianggap sebagai eksperimen yang tidak sebenarnya disebut quasi eksperimen, dengan metode pretest dan post test with control group dimana dalam rancangan ini seperti rancangan pretest dan posttest, dan memiliki grup kontrol. (Notoatmodjo, 2018).

\section{HASIL}

Lokasi penelitian ini di Wilayah Kerja Puskesmas Gedung Sari Lampung tengah yang berdiri sejak tahun 2004 yang beralamatkan di Desa Gedung Sari, Kecamatan Anak Ratu Aji, Kabupaten Lampung Tengah, Provinsi Lampung. Jenis pelayanan pada Puskesmas Anak Ratu Aji adalah Poli Umum, Poli KIA, MBS, Poli Gigi, Pasien Rawat Jalan. Rujukan hingga Farmasi. Sarana yang tersedia adalah satu Ruang Administrasi, satu Ruang Jaga Petugas, empat Ruang Periksa dan satu Ruang Farmasi. 
Karakteristik responden dapat dilihat pada tabel berikut ini:

Tabel 1.

Karakteristik Responden Berdasarkan Umur

\begin{tabular}{ccccc}
\hline \multirow{2}{*}{ Umur Responden } & \multicolumn{2}{c}{ Kelompok Eksperimen } & \multicolumn{2}{c}{ Kelompok Kontrol } \\
\cline { 2 - 5 } & Frekuensi & Presentase (\%) & Frekuensi & Prentase (\%) \\
\hline × 20 Tahun & 0 & 0 & 0 & 0 \\
20 - 35 Tahun & 19 & 95 & 18 & 90 \\
$\geq 35$ Tahun & 1 & 5 & 2 & 10 \\
\hline Jumlah & 20 & 100 & 20 & 100 \\
\hline
\end{tabular}

Berdasarkan tabel 1 didapatkan hasil ibu dengan umur responden $\leq 20$ Tahun pada kelompok eksperimen sebanyak $0(\%)$ pada kelompok kontrol sebanyak $0(\%)$, umur responden 20 - 35 Tahun pada kelompok eksperimen sebayak 95(\%)pada kelompok kontrol sebanyak 90 (\%) dan umur responden $\geq 35$ Tahun pada kelompok eksperimen sebanyak $5(\%)$ pada kelompok kontrol sebanyak $10(\%)$.

Tabel 2.

Karakteristik Responden Paritas

\begin{tabular}{ccccc}
\hline \multirow{2}{*}{ Paritas } & \multicolumn{2}{c}{ Kelompok Eksperimen } & \multicolumn{2}{c}{ Kelompok Kontrol } \\
\cline { 2 - 5 } & Frekuensi & Presentase (\%) & Frekuensi & Presentase (\%) \\
\hline Primipara & 7 & 35 & 8 & 30 \\
Multipara & 12 & 65 & 14 & 70 \\
\hline Jumlah & 20 & 100 & 20 & 100 \\
\hline
\end{tabular}

Berdasarkan tabel 2 didapatkan hasil paritas responden yang primipara pada kelompok eksperimen sebayak $35(\%)$ pada kelompok kontrol sebanyak $30(\%)$ dan multipara pada kelompok eksperimen sebanyak $65(\%)$ sedangkan pada kelompok kontrol sebanyak 70 (\%).

Tabel 3.

Rata-rata Produksi ASI Ibu Menyusui Sebelum dan Sesudah Mengkonsumsi Daun Kelor di Wilayah Kerja Puskesmas Gedung Sari Lampung Tengah Tahun 2019

\begin{tabular}{lccccc}
\hline \multicolumn{1}{c}{ Variable } & N & Min & Max & Mean & SD \\
\hline Pre-test produksi ASI sebelum mengkonsumsi kapsul daun kelor & 20 & 5 & 55 & 26.50 & 14.699 \\
Post-test produksi ASI sesudah mengkonsumsi kapsul daun kelor & 20 & 60 & 120 & 80.50 & 16.772 \\
\hline
\end{tabular}

Berdasarkan tabel 3 diketahui bahwa 20 responden penelitian, diperoleh hasil nilai mean atau nilai rata - rata produksi ASI ibu menyusui sebelum mengkonsumsi kapsul daun kelorkelompok eksperimen adalah sebesar 26.50, dengan nilai minimum produksi ASI 5 dan nilai maximum 55 , serta nilai standar deviasi sebesar 14.699. sedangkan nilai mean atau nilai rata - rata produksi ASI ibu menyusui sesudah mengkonsumsi kapsul daun keloreksperimen adalah sebesar 80,50 dengan nilai minimum 60 dan nilai maximum 120, serta nilai standar deviasi sebesar 16.772 .

Hasil dari penelitian ini sejalan dengan penelitian yang telah dilakukan oleh Ma. Corazon $\mathrm{P}$. Estrella, M.Ddengan judul 'A double-blind, randomized controlled trial on the use of malunggay (Moringa oleifera) for augmentation of the volume ofbreastmilk among non-nursing mothers of preterm infants.", 
Tabel 4.

Rata-rata Produksi ASI Ibu Menyusui Sebelum dan Sesudah Mengkonsumsi Kapsul Kosong di Wilayah Kerja Puskesmas Gedung Sari Lampung Tengah Tahun 2019

\begin{tabular}{lccccc}
\hline \multicolumn{1}{c}{ Variabel } & N & Min. & Max. & Mean & SD \\
\hline Pre-test produksi ASI sebelum mengkonsumsi kapsul kosong & 20 & 5 & 50 & 29.25 & 12.802 \\
Post-test produksi ASI sesudah mengkonsumsi kapsul kosong & 20 & 20 & 65 & 46.00 & 11.987 \\
\hline
\end{tabular}

Berdasarkan tabel 4 diketahui bahwa 20 responden penelitian, diperoleh hasil nilai mean atau nilai rata - rata produksi ASI ibu menyusui sebelum mengkonsumsi kosongkelompok kontrol adalah sebesar 29.25, dengan nilai minimum produksi ASI 5 dan nilai maximum 50 , serta nilai standar deviasi sebesar 12.802. sedangkan nilai mean atau nilai rata - rata produksi ASI ibu menyusui sesudah mengkonsumsi kapsul daun keloreksperimen adalah sebesar 80,50 dengan nilai minimum 60 dan nilai maximum 120, serta nilai standar deviasi sebesar 16.772.

Tabel 5.

Pengaruh Pemberian Kapsul Daun Kelor Terhadap Produksi ASI di Wilayah Kerja Puskesmas Gedung Sari Tahun 2019

\begin{tabular}{|c|c|c|c|c|c|c|c|c|}
\hline \multirow[t]{2}{*}{ Variabel } & \multirow[t]{2}{*}{$\mathbf{N}$} & \multirow[t]{2}{*}{ Mean } & \multirow[t]{2}{*}{$T$} & \multirow{2}{*}{$\begin{array}{l}\text { Std. } \\
\text { Deviati } \\
\text { on }\end{array}$} & \multirow[t]{2}{*}{$\begin{array}{l}\text { S.Eror } \\
\text { Mean }\end{array}$} & \multirow[t]{2}{*}{$P$ value } & \multicolumn{2}{|c|}{$\begin{array}{l}95 \% \text { confidence } \\
\text { interval of the } \\
\text { diference }\end{array}$} \\
\hline & & & & & & & Lower & Upper \\
\hline $\begin{array}{l}\text { Selisih Mean Post-test (-) } \\
\text { Pre-test eksperimen }\end{array}$ & 20 & 54 & 7.484 & 16.772 & 3.750 & \multirow{2}{*}{0.000} & 25.168 & 43.832 \\
\hline $\begin{array}{l}\text { Selisih Mean Post-test (-) } \\
\text { Pre-test Kontrol }\end{array}$ & 20 & 16.74 & 7.484 & 11.987 & 2.680 & & 25.136 & 43.864 \\
\hline
\end{tabular}

Berdasarkan tabel 5 didapatkan hasil ratarata kenaikan produksi ASI ibu menyusui yang sudah mengkonsumsi kapsul kelor pada kelompok eksperimen sebesar 54 dan rata rata kenaikan produksi ASI ibu menyusui yang mengkonsumsi kapsul kosong pada kelompok kontrol sebesar 16.74. Uji $t$ independent didapat $p$ value $0,000, a$ $(0,05)$ artinya h0 ditolak dan ha diterima, yang berarti ada pengaruh konsumsi kapsul daun kelor terhadap produksi ASI di Wilayah Kerja Puskesmas Gedung Sari tahun 2019.

\section{PEMBAHASAN}

Analisa Univariat dilakukan pada tiap variabel kelompok eksperimen dalam bentuk table distribusi frekuensi produksi ASI ibu menyusui sebelum dan sesudah mengkonsumsi kapsul daun kelor di Wilayah Kerja Puskesmas Gedung Sari Lampung Tengah Tahun 2019.

Kelompok diberi Moringa oleifera daun dalam persiapan kapsul komersial $250 \mathrm{mg}$ setiap 12 jam mulai tanggal 3 hari pascapersalinan.

Setelah orientasi yang tepat, demonstrasi dan pelatihan, ibu kemudian disusun untuk memompa payudara mereka setiap 4 jam menggunakan pompa payudara standar. Volume diukur menggunakan standar wadah dan dicatat dalam catatan standarbuku yang disediakan oleh personel studi. Bila tersedia, volume susu Terpantau juga diukur oleh penelitian personil. Total volume susu adalah rata-rata volume ASI 114,1 $\pm 62,9 \mathrm{m1}$.

Berdasarkan hasil statisti uji independen sampletest dengan program SPSS dengan $p$ value $0,000<a(0,05)$. ini berarti ada pengaruh konsumsi kapsul daun kelor terhadap produksi ASI.

Menurut pendapat peneliti berdasarkan hasil penelitian bahwa produksi ASI setiap ibu pada kelompok eksperimen berbeda beda, hal ini dikarenakan selain mengkonsumsi daun kelor yang kandungan nutrisinya banyak, ibu juga mendapatkan nutrisi dari makanan yang di konsumsi setiap hari. Sehingga produksi ASI setiap ibu berbeda beda. Selain itu juga ada faktor lain sepertiumur ibu, ibu yang umurnya $\leq 20$ tahun pada kelompok eksperimen tidak ada, umur ibu 20-35 tahun pada kelompok eksperimen sebanyak 19 orang (95\%) dimana usia ini adalah usia produktif sehingga akan memiliki tingkat produksi ASI lebih banyak dibandingkan dengan ibu yang umur $\leq 20$ tahun, dan umur ibu $\geq 35$ tahun 1 orang (5\%). Paritas pada ibu juga dapat mempengaruhi produksi ASI. Pada kelompok eksperimen primipara pada kelompok eksperimen sebayak 7 orang (35\%) multipara pada kelompok eksperimen sebanyak 13 orang (65\%) 
dimana ibu yang multipara produksi ASInya lebih banyak dibandingkan dengan ibu primipara.

Berdasarkan hasil penelitian dapat diketahui bahwa 20 responden penelitian, diperoleh hasil nilai mean atau nilai rata - rata produksi ASI ibu menyusui sebelum mengkonsumsi kapsul kosongkelompok kontrol adalah sebesar 29.25, dengan nilai minimum produksi ASI 5 dan nilai maximum 50 , serta nilai standar deviasi sebesar 12.802 .

Hal ini sesuai dengan teori bahwa mengkonsumsi Daun kelor yang mengandung fitosterol dapat meningkatkan produksi ASI bagi wanita yang sedang menyusui dan mengatasi masalah anemia pada anak-anak dan ibu hamil. Ekstrak daun kelor mengandung Fe 5,49 mg/100g, sistosterol 1,15\%/100 g dan stigmasetol 1,52\%/100 g.

Hasil dari penelitian ini sejalan dengan penelitian yang telah dilakukan oleh Ma. Corazon $\mathrm{P}$. Estrella, M.Ddengan judul 'A double-blind, randomized controlled trial on the use of malunggay (Moringa oleifera) for augmentation of the volume ofbreastmilk among non-nursing mothers of preterm infants.", Untuk kelompok Kontrol di beri kapul kosong (placebo).

Menurut pendapat peneliti berdasarkan hasil penelitian bahwa produksi ASI pada ibu menyusuiterjadi peningkatan pada kelompok kontrol. Hal ini dikarenakan ibu mendapatkan nutrisi dari makanan yang di konsumsi setiap hari. Selain itu, kebiasaan ibu yang sering memberikan ASInya dapat mempengaruhi tingkat produksi ASI. faktor lain seperti umur ibu, ibu yang umurnya $\leq 20$ tahun pada kelompok kontrol tidak ada, umur ibu 20-35 tahun pada kelompok kontrol sebanyak 18 orang $(90 \%)$ dimana usia ini adalah usia produktif sehingga akan memiliki tingkat produksi ASI lebih banyak dibandingkan dengan ibu yang umur $\leq 20$ tahun, dan umur ibu $\geq 35$ tahun 2 orang (10\%). Paritas pada ibu juga dapat mempengaruhi produksi ASI. Pada kelompok kontrol primipara pada kelompok eksperimen sebayak 8 orang (40\%) multipara pada kelompok kontrol sebanyak 14 orang $(60 \%)$ dimana ibu yang multipara produksi ASInya lebih banyak dibandingkan dengan ibu primipara.

Berdasarkan hasil penelitian diatas didaptkan hasil uji independent didapat $p$ value $0,000, a(0,05)$ artinya h0 ditolak dan ha diterima, yang berarti ada pengaruh pemberian kapsul daun kelor terhadap produksi ASI di wilayah kerja Puskesmas Gedung Sari Lampung Tengah Tahun 2019.

Hal ini sesuai dengan teori bahwadaun kelor adalah ramuan yang meningkatkan volume dan memperlancar aliran ASI. Beberapa studi mengkonfirmasi kemanjuran daun kelor dalam membantu ibu menyusui. Daun kelor meningkatkan efek laktasi yang dibuktikan dengan peningkatan yang lebih besar dalam kadar prolaktin serum ibu. Prolaktin merupakan hormone yang paling penting dalam inisiasi laktasi. Serbuk daun kelor yang efektif untuk meningkatkan volume dan memperlancar ASI.(Krisnadi, 2015)

Setiap $100 \mathrm{~g}$ daun kelor mengandung $3390 \mathrm{SI}$ vitamin $\mathrm{A}$, yaitu dua kali lebih tinggi dari bayam dan 30 kali lebih tinggi dari buncis. Daun kelor juga tinggi kalsium, sekitar $440 \mathrm{mg} / 100 \mathrm{~g}$, serta $70 \mathrm{mg} / 200$ g.Kandungan gizi inilah yang menyebabkan kandungan daun kelor sebagai salah satu tumbuhan yang bsia memperlancar produksi ASI.(Astutik, 2014). Oleh karena itu, dari kandungan nutrisi yang ada pada kapsul daun kelor tersebut, maka dengan megkonsumsi kapsul daun keloribu menyusui dapat meningkatkan produksi ASInya.

Hasil dari penelitian ini sejalan dengan penelitian yang telah dilakukan oleh Ma. Corazon P. Estrella, M.Ddengan judul 'A double-blind, randomized controlled trial on the use of malunggay (Moringa oleifera) for augmentation of the volume ofbreastmilk among non-nursing mothers of preterm infants.",

Kelompok diberi Moringa oleifera daun dalam persiapan kapsul komersial 250 mg setiap 12 jam mulai tanggal 3 hari pascapersalinan.Berdasarkan hasil statisti uji independen sample test dengan program SPSS dengan $p$ value $0,000<\alpha(0,05)$. ini berarti ada pengaruh konsumsi kapsul daun kelor terhadap produksi ASI.

Menurut peneliti dari hasil independen sample test dengan program SPSS dibuktikan bahwa mean kelompok eksperimen yang mengkonsumsi kapsul daun kelor yakni 54 dan sdt.deviation 16.772 lebih efektif dikonsumsi dari pada kelompok kontrol dengan mengkonsumsi kapsul kosong dengan mean 16.74 dan sdt.deviation 11.987.

Menurut pendapat peneliti berdasarkan hasil penelitian bahwa produksi ASI setiap ibu pada kelompok eksperimen berbeda beda, hal ini dikarenakan selain mengkonsumsi daun kelor yang kandungan nutrisinya banyak, ibu juga mendapatkan nutrisi dari makanan yang di konsumsi setiap hari. Sehingga produksi ASI setiap ibu berbeda beda. Selain itu ada faktor lain yang mempengaruhi yaitu umur ibu, paritas, lama kehamilan, dan berat badan ibu. Pada kelompok kontrol terjadi peningkatan produksi ASI, dikarenakan ibu mendapatkan nutrisi dari makanan yang di konsumsi setiap hari. Selain itu, kebiasaan ibu yang sering memberikan ASInya dapat mempengaruhi tingkat produksi ASI. Namun, peningkatan produksi ASI pada kelompok kontrol 
tidak sebesar pada kelompok eksperimen hal ini dapat di lihat dari rata-rata kenaikan produksi ASI pada kelompok eksperimen sebesar 54 sedangkan pada kelompok kontrol sebesar 16,74.

\section{KESIMPULAN}

Diketahui rata-rata frekuensi sebelum pemberian kapsul daun kelor terhadap produksi ASI di wilayah kerja Puskesmas Gedung Sari Lampung Tengah Tahun 2019 Tahun 2019 Yaitu 26.50, diketahui rata-rata frekuensi sesudah pemberian kapsul daun kelor terhadap produksi ASI di wilayah kerja Puskesmas Gedung Sari Lampung Tengah Tahun 2019 Yaitu 80.50,diketahui rata-rata frekuensi sebelum pemberian kapsul kosong terhadap produksi ASI di wilayah kerja Puskesmas Gedung Sari Lampung Tengah Tahun 2019 Yaitu 29.25, diketahui rata-rata frekuensi sesudahpemberian kapsul kosong terhadap produksi ASI di wilayah kerja Puskesmas Gedung Sari Lampung Tengah Tahun 2019 Yaitu 46.00, diketahui ada pengaruh pemberian pemberian kapsul daun kelor terhadap produksi ASI di wilayah kerja Puskesmas Gedung Sari Lampung Tengah Tahun 20199 . Hasil uji T didapat $p$ value $0,000<a$ $(0,05)$.

\section{SARAN}

Bagi Masyarakat, Dianjurkan kepada para ibu menyusui untuk mengkonsumsi kapsul daun kelor karena kapsul kelor dapat meningkatkan produksi ASI. Bagi Peneliti Selanjutnya, dapat mengembangkan penelitian ini sehingga dapat membandingkan tingkat keberhasilan dengan kelompok kontrol maupun memodifikasi teknik tersebut dengan berbagai macam teknik dan variabel lain yang dapat digunakan untuk meningkatkan produksi ASI.

\section{DAFTAR PUSTAKA}

Asih, Yusri dan Risneni. (2016). Asuhan Kebidanan Nifas dan Menyusui. Jakarta: TIM.

Astutik, R.Y. (2014). Payudara dan Laktasi.
Badan Penelitian dan Pengembangan Kesehatan, K.R. (2013). Riset Kesehatan Dasar.

Dewi, V. N. L. (2012). Asuhan Kebidanan pada Ibu Nifas. Jakarta: Salemba Medika.

Dinas Kesehatan, P. L. (2016). Profil Kesehataan Provinsi Lampung, (44).

Gopalakrishnan, L., Doriya, K., \& Santhosh, D. (2016). Moringa Oleifera : A Review on Nutritive Importance and It's Medician Application. Food Science and Human Wellness, 5(2), 49-56. https://doi.org/10.1016/j.fshw.2016.04.001

Kent, J. C. (2011). Principles for Maintaining or Increasing Breast Milk Production. Journal of Obstretic Gynecologic and Neonatal Nursing, 41

114-121. https://doi.org/10.1111/j.15526909.2011.01313.x

Kent, J. C. Gardner, H., \& Geddes, D. T. (2016). Breastmilk Production in the First 4 Weeks After Birth of Term Infants, 9-14. https://di.org/10.3390/nu8120756

Krisnadi, A. D. (2015). Kelor Supernutrisi. Blora: LSM Mepeling.

Ma. Corazon P. Estrella, M. D., Jacinto Bias V. Man Taring III, M.D., Grace Z. David, M.D., Michelle A. Taup, M. (2000). A Double-Blind, Randomized Controller Trial on The Use of Malunggay (Moringa Oleifera) For Augmentation of The Volume of Breastmilk among non-nursing Mothers of Preterm Infants.

Maryunani, A. (2012). IMD, ASI Eksklusif, dan Manajemen Laktasi.

Notoatmodjo, S. (2018). Metodologi Penelitian Kesehatan. Jakarta: Rineka Cipta.

Prawirohardjo, S. (2014). IImu Kebidanan. Jakarta: Balai Pustaka.

Sulistiawati, Y., Suwondo, A., Hardjanti, T. S., Soejoenoes, A., \& Choiroel, M. (2017). Effect of Moringa Oleifera on Level of Prolactin and Breastmilk Production in Postpartum Mothers, 3(2), 126-133.

Yusni, K. (2009). Pengobatan Alternatif dengan Aneka Tanaman Obat. Jakarta: Rinka Medika. 